\title{
Quality of fresh and seasoned fat of Cinta Senese pigs as affected by fattening with chestnut
}

\author{
C. Pugliese *, F. Sirtori, A. Acciaioli, R. Bozzi, G. Campodoni, O. Franci \\ Dipartimento di Biotecnologie Agrarie, Sezione di Scienze Animali, Via delle Cascine, 5, 50144 Firenze, Italy
}

\section{A R T I C L E I N F O}

\section{Article history:}

Received 15 February 2012

Received in revised form 13 July 2012

Accepted 4 August 2012

\section{Keywords:}

Cinta Senese

Pigs

Chestnut

Meat quality

Fatty acid

Seasoned fat

\begin{abstract}
A B S T R A C T
This trial was aimed to verify the effect of fattening with chestnut on carcass characteristics and on quality traits of products of Cinta Senese breed. Thirty-three Cinta Senese pigs were allotted into three groups. One group was fed a commercial feedstuff $(0-\mathrm{CH})$, the other two groups were fed chestnut for one (1-CH) or three (3-CH) months. Pigs were slaughtered at $130 \mathrm{~kg}$ of live weight. The 1-CH group showed significantly lower $\mathrm{pH}$ value at $24 \mathrm{~h}(\mathrm{P}<0.05)$. For sample joint dissection a significant effect $(\mathrm{P}<0.05)$ of feeding system was found only on intermuscular fat, highest in $1-\mathrm{CH}$. A significant effect of feeding system $(\mathrm{P}<0.05)$ was found on physical and chemical parameters of Longissimus lumborum: the 3-CH group showed the highest values $(\mathrm{P}<0.05)$ of $\mathrm{L}^{*}, \mathrm{a}^{*}, \mathrm{~b}^{*}$, drip loss, cooking loss, shear force and intramuscular fat on raw meat. The $3-\mathrm{CH}$ showed significantly higher level $(\mathrm{P}<0.05)$ of unsaturation for the highest percentage of MUFA and PUFA.
\end{abstract}

(c) 2012 Elsevier Ltd. All rights reserved.

\section{Introduction}

Cinta Senese is a local pig breed reared mainly in Tuscany. Among the Italian autochthonous pig breeds, the Cinta Senese has good perspectives of increasing its relevance due to the high number of animals raised and the strong link with the Tuscan territory. Currently the breed is one of the most interesting examples of recovery and preservation of native germplasm preservation (Franci \& Pugliese, 2007). Grazing in a forest is used for various extents of time for Cinta Senese pig and this type of rearing allows growers to exploit feed resources that would be otherwise unused.

Recently, the Cinta Senese meat obtained the Protected Designation of Origin (PDO). The rules of the PDO, require that, to obtain the designation, it is necessary to rear animals outdoors, grazing in the forest or in the pasturable land. Consequently it is very important to know the effect of outdoor rearing system on fresh and cured product quality.

The effect of the rearing system on quality of the products of local pigs, has been studied both on physical (Lopez-Bote et al., 2008; Pérez-Palacios et al., 2010; Pugliese et al., 2004, 2005) and chemical traits (Andrés et al., 2001; Cava, Ruiz, Ventanas, \& Antequera, 1999a; Cava, Ventanas, Tejeda, Ruiz, \& Antequera, 2000; Coutron-Gambotti, Gandemer, \& Casabianca, 1998; Diaz, Garcia Regueiro, Casillas, \& De Pedro, 1996; Pugliese, Pianaccioli, Sirtori, Acciaioli, \& Franci, 2007; Pugliese, Sirtori, D'Adorante, et al., 2009; Pugliese, Sirtori, Ruiz, et al.,

\footnotetext{
* Corresponding author. Tel.: + 390553288263 ; fax: + 39055321216.

E-mail address: carolina.pugliese@unifi.it (C. Pugliese).
}

2009). Due to the rearing systems of the local pig breeds (almost always outdoors), these studies mainly report the effect on quality of the products of the combined results of both the farming system and the feeding regimen. The latter, for the pigs reared in forest, is often the combination of contemporary ingestion of grass and acorn and/or chestnut. Knowledge of the effect of providing of acorn or chestnut in controlled rearing conditions is very scarce (Coutron-Gambotti et al., 1998; Zumbo et al., 2007). Even more scarce is information on the minimum period of administration of these diets that allows the characteristics of the products to develop.

Nowadays, one of the main problems in the rearing of Cinta Senese pigs is linked to the use of the forest that, in many cases, occurs in an inadequate way. Frequently, the number of animals per hectare is very high and the period of pasture in the forest is longer than the time of effective availability of natural sources, causing irreparable damage to the soil, to the tree and also to the underbrush, which often is completely destroyed (Campodoni, Acciaioli, \& Bozzi, 2010). Therefore, it would be very useful to know the minimal period of feeding of wood fruits (chestnut and/or acorn) to obtain a marked difference in the final product.

Cured lard is a typical Italian dry cured product that is now back in vogue as a gourmet product, flanking other well known Italian lards such Arnaud and Colonnata. The lard of Cinta Senese is usually seasoned with a dry-seasoning technique, contrary to Colonnata lard, which is cured in brine. The curing time can vary from 3 to 6 months, it depends on the technique which can vary from one producer to another (Pugliese, Sirtori, D'Adorante, et al., 2009).

The primary aim of this study was to determine the effect of the administration of chestnuts for a variable period during fattening, 
on the chemical and physical characteristics of fresh meat and fat and on the seasoned lard. Other specific objectives were to compare fatty acid composition of subcutaneous fat tissues both of different layers (outer and inner) and during the seasoning period.

\section{Materials and methods}

\subsection{Animals and diets}

The trial was carried out indoors to better evaluate the effect of chestnuts during the fattening period in a controlled system, even though the indoor system is not the usual form of rearing of Cinta Senese pigs.

Thirty-three pigs, at an average weight of $97 \mathrm{~kg}$ and 289 days old, were employed (Table 1). The final target weight was $130 \mathrm{~kg}$, and the age at slaughter was 378 days, on average; it was greater than 12 months, which is the minimum slaughtering age imposed by the specification of the PDO. During the fattening period (last 3 months before slaughtering), the animals were allotted into three groups, balanced for sex, age and live weight. One group was fed a commercial mixture $(0-\mathrm{CH})$ for the whole fattening period, a second group (1-CH) was fed the same mixture during the first 2 months and chestnut during the last month; a third group (3-CH) was fed chestnut during the all 3 months of the trial. Chestnuts for groups 1 and 3- $\mathrm{CH}$ were inclusive of the shell. In addition to the chestnuts $10 \%$ of bran was also given to assure the regularity of intestinal functions. Diets were distributed to ensure similar DE intake among the groups, as reported in Table 1 that details the diet characteristics and the pigs' average feed intake. Before the experimental period animals were reared together and fed the same commercial feedstuff.

The chemical analyses of feed were carried out following the methods reported below. At the end of the trial period, animals were slaughtered, in the same public slaughterhouse, on three distinct days within 2 weeks.

\subsection{Carcass measures and seasoning process}

At slaughtering, the thickness of backfat was recorded at the last thoracic vertebra (LT) and at the Gluteus medius (Gm) level. At $45 \mathrm{~min}$ $\left(\mathrm{pH}_{45}\right)$ and $24 \mathrm{~h}\left(\mathrm{pH}_{24}\right)$ post-mortem, $\mathrm{pH}$ was measured on Longissimus lumborum muscle, near the 10th lumbar vertebra. The day after slaughtering, a sample of the loin (portion of loin from 2nd to 5th lumbar vertebra), inclusive of subcutaneous fat and skin, was removed. The sample of the loin was dissected into lean, fat and bone. The lean portion was separated in Longissimus lumborum (LL), Psoas major (PM) and "other muscles"; subcutaneous fat was separated in outer and inner layers. Each portion was weighed. The backfat of the lumbar region of the left side was sectioned off in blocks and completely covered by a

Table 1

Daily feed intake and nutritive characteristics of the diets.

\begin{tabular}{lll}
\hline & Chestnut $^{\mathrm{a}}$ & Mixture $^{\mathrm{b}}$ \\
\hline $\begin{array}{l}\text { Feed intake (kg d.m./day/head) } \\
\text { Diet composition }\end{array}$ & 2.7 & 2.7 \\
$\quad$ Crude protein (g/kg d.m.) & 55.4 & 189 \\
$\quad$ Digestible energy (kcal/kg d.m.) & 3029 & 2958 \\
Energy/protein (kcal/g) & 54.7 & 15.7 \\
Fatty acids (g/kg d.m.) & & \\
SFA & 3.9 & 2.6 \\
MUFA & 9.1 & 3.0 \\
PUFA $-\mathrm{n}-3$ & 1.6 & 0.7 \\
PUFA $-\mathrm{n}-6$ & 9.2 & 7.2
\end{tabular}

a $10 \%$ of wheat bran was added.

b Ingredients (g/kg): maize (330); barley (270); wheat bran (220); soybean meal (150); and supplement (30). mixture composed of sea salt and pepper (150 g of pepper/1000 g of sea salt) and kept in a cold room $\left(4{ }^{\circ} \mathrm{C}\right.$ and $\mathrm{RH}$ of $\left.80 \%\right)$. After 1 month of salting the salt/pepper mixture was removed and the seasoning process continued, under the same environmental conditions, for another 2 months. The seasoning was carried out in a small salami factory where onsite equipment was used. At $0,30,60$ and 90 days of seasoning the lard was sampled (about $50 \mathrm{~g}$ of product), the samples were stored at $-80{ }^{\circ} \mathrm{C}$ until the analysis.

\subsection{Chemical and physical analyses}

Twenty-four hours after slaughtering, on LL the following physical determinations were carried out:

1) colour measurement $\left(L^{*}, a^{*}\right.$ and $\left.b^{*}\right)$ by Minolta Chromameter $C R-200$ : it was taken 24 -h post-mortem on the cut surface, after $1 \mathrm{~h}$ rest at $4{ }^{\circ} \mathrm{C}$, according to official method (Boccard et al., 1981); the hue angle $\left(\mathrm{H}^{\circ}=\arctan \left(\mathrm{b}^{*} / \mathrm{a}^{*}\right)\right)$ and Chroma $\left(\mathrm{C}^{*}=\left(\left(\mathrm{a}^{*}\right)^{2}+\left(\mathrm{b}^{*}\right)^{2}\right)^{0.5}\right)$ parameters were also calculated.

2) water-holding capacity (WHC) by the techniques proposed by Grau and Hamm (1952) and modified by Pugliese et al. (2005): drip loss on slices stored horizontally for $48 \mathrm{~h}$; cooking loss after boiling the meat samples in water-bath until the centre temperature reached $75^{\circ} \mathrm{C}$; free water by filter paper press method.

3 ) shear force by Instron 1011 apparatus on raw and cooked meat: two cylindrical cores $(\varnothing 2.54 \mathrm{~cm})$ parallel with the fibre direction, are sheared by a V-shaped blade with an angle of $60^{\circ}$ at a velocity of $100 \mathrm{~mm} / \mathrm{min}$ (Boccard et al., 1981). The maximal forces for the cylindrical cores are averaged to obtain one value per sample.

On LL and PM muscles the following chemical analyses were carried out according to AOAC methods (1990):

1) moisture by lyophilising to constant weight;

2) intramuscular fat (IMF) as ether extract;

3) protein percentage by Kjldahl method.

Fresh and cured fat samples were analysed for:

1) colour measurements according to the previously mentioned method;

2) total lipid content (Folch, Lees, \& Stanley, 1957);

3) fatty acid profile of total lipids. Fatty acid methyl esters were prepared by esterification in the presence of sulphuric acid and were analysed by gas chromatography using a DANI 86.10 apparatus equipped with a flame ionisation detector (FID). Fatty acid separation occurred in a capillary column coated with FFAP-TPA stationary phase (30 m length; $0.32 \mathrm{~mm}$ internal diameter; $0.25 \mu \mathrm{m}$ film thickness). The temperature of the column started at $160{ }^{\circ} \mathrm{C}$ and reached $220^{\circ} \mathrm{C}$, increasing $2{ }^{\circ} \mathrm{C} / \mathrm{min}$. Temperature of the detector was set at $260{ }^{\circ} \mathrm{C}$. The individual methyl esters were identified by their retention time. Results are expressed as percentage of total fatty acids.

4) free malondialdehyde (MDA) content, determined according to the method of Pikul, Leszczynski, and Kummerow (1983): $2.4 \mathrm{~g}$ of tissue was homogenised in $4 \mathrm{ml}$ of BHT $0.01 \mathrm{~g} / \mathrm{ml}$ chloroform and $15 \mathrm{ml}$ TCA (5\%). The homogenate was centrifuged for $15 \mathrm{~min}$ at $2000 \mathrm{rpm}$ at $4{ }^{\circ} \mathrm{C}$ and $2 \mathrm{ml}$ of the aqueous supernatant was added to $3 \mathrm{ml} \mathrm{TBA} 0.02 \mathrm{M}$. When the solution was coloured the $\mathrm{pH}$ was adjusted to approximately 7 , then the solution was filtered with chromatographic cartridges to obtain the solid phase extraction (Sep-Pak Cartridges, waters Corporation, Massachusetts) and remove extraneous products. Finally a colour reading was made with spectrophotometer (PerkinElmer EZ-150) at a wavelength of $535 \mathrm{~nm}$. MDA content was expressed in $\mathrm{mg} / \mathrm{kg}$ of total lipids. 


\subsection{Statistical analysis}

The GLM procedure of SAS (2003) was used to analyse the data of the factorial experimental design according to the following models:

1) For live animal data:

$\mathrm{Y}_{\mathrm{ijk}}=\mu+\mathrm{D}_{\mathrm{i}}+\mathrm{S}_{\mathrm{j}}+\mathrm{e}_{\mathrm{ijk}}$.

Where: $Y$ is the kth observation, $\mu$ is the overall mean, $D$ is the ith diet; $S$ is the jth sex and $e_{i j k}$ is the error which is an independent random variable.

2) For carcass characteristics and sample joint composition:

$\mathrm{Y}_{\mathrm{ijk}}=\mu+\mathrm{D}_{\mathrm{i}}+\mathrm{S}_{\mathrm{j}}+\mathrm{b} * \mathrm{X}_{\mathrm{ijk}}+\mathrm{e}_{\mathrm{ijk}}$.

Where: $\mathrm{Y}$ is the kth observation, $\mu$ is the overall mean, $\mathrm{D}$ is the ith diet; $\mathrm{S}$ is the jth sex; $\mathrm{b}$ is the regression coefficient on live weight (X) and $\mathrm{e}_{\mathrm{ijk}}$ is the error which is an independent random variable.

3) For chemical-physical analysis of muscles:

$\mathrm{Y}_{\mathrm{ijkl}}=\mu+\mathrm{D}_{\mathrm{i}}+\mathrm{S}_{\mathrm{j}}+\mathrm{M}_{\mathrm{k}}+\mathrm{D}_{\mathrm{i}} * \mathrm{M}_{\mathrm{k}}+\mathrm{b}_{\mathrm{i}} * \mathrm{X}_{\mathrm{ijk} \mathrm{l}}+\mathrm{e}_{\mathrm{ijk} \mathrm{k}}$.

Where, besides the above indication, $\mathrm{M}$ is the kth muscle (only for chemical analysis).

4) For chemical-physical analysis of fresh and seasoned fat:

$\mathrm{Y}_{\mathrm{ijkl}}=\mu+\mathrm{D}_{\mathrm{i}}+\mathrm{S}_{\mathrm{j}}+\mathrm{L}_{\mathrm{k}}+\mathrm{b}_{\mathrm{i}} * \mathrm{X}_{\mathrm{ijkl}}+\mathrm{e}_{\mathrm{ijkl}}$.

Where, besides the above indication, $\mathrm{L}$ is the kth layer of fat.

\section{Results and discussion}

In Table 2 the means of live animal performance, carcass traits and product characteristics are shown. No differences were found for age, weight and average daily gain during the fattening period, indicating the good balance of the initial conditions and the same nutritive value of the three feeding regimens.

With respect to the carcass characteristics, the only parameter affected by the feeding system was $\mathrm{pH}_{24}$ where 1-CH group showed

Table 2

Live animal performance, backfat thickness and sample joint composition.

\begin{tabular}{|c|c|c|c|c|}
\hline & \multicolumn{3}{|l|}{ Diet } & \multirow[t]{2}{*}{ RSD } \\
\hline & $0-\mathrm{CH}$ & $1-\mathrm{CH}$ & $3-\mathrm{CH}$ & \\
\hline Initial age $(\mathrm{d})$ & 288.4 & 293.5 & 284.8 & 44.18 \\
\hline Slaughter age (d) & 391.4 & 389.5 & 373.8 & 44.18 \\
\hline Initial weight ( $\mathrm{kg}$ ) & 95.75 & 97.07 & 97.25 & 17.47 \\
\hline Slaughter weight (kg) & 132.0 & 130.4 & 127.4 & 19.55 \\
\hline $\mathrm{pH}_{45}$ & 6.41 & 6.42 & 6.43 & 0.24 \\
\hline $\mathrm{pH}_{24}$ & 5.61a & $5.42 \mathrm{~b}$ & $5.61 \mathrm{a}$ & 0.14 \\
\hline ADG $(g)$ & 351 & 347 & 339 & 68 \\
\hline Fat thickness at LT $(\mathrm{mm})^{*}$ & 36.94 & 34.54 & 37.62 & 5.75 \\
\hline Fat thickness at $\mathrm{Gm}(\mathrm{mm})^{*}$ & 41.17 & 39.53 & 42.86 & 8.11 \\
\hline Sample joint weight $(\mathrm{kg})^{*}$ & 2.10 & 2.14 & 1.97 & 0.28 \\
\hline \multicolumn{5}{|l|}{ Sample joint composition (\%) } \\
\hline Total lean & 46.20 & 44.40 & 43.47 & 3.99 \\
\hline Longissimus lumborum & 30.01 & 28.38 & 28.07 & 2.60 \\
\hline Psoas major & 9.57 & 9.30 & 8.90 & 1.08 \\
\hline Other lean & 6.63 & 6.73 & 6.50 & 1.21 \\
\hline Subcutaneous fat & 42.79 & 42.29 & 42.47 & 4.57 \\
\hline Outer layer & 18.87 & 19.29 & 17.58 & 2.52 \\
\hline Inner layer & 23.91 & 23.00 & 24.89 & 3.87 \\
\hline Intermuscular fat & $2.32 \mathrm{~b}$ & $4.47 a$ & $3.82 \mathrm{ab}$ & 1.73 \\
\hline Bone & 8.69 & 8.84 & 10.24 & 2.09 \\
\hline Lean/fat & 1.05 & 0.99 & 0.96 & 0.21 \\
\hline
\end{tabular}

$0-\mathrm{CH}=$ fattening without chestnut; $1-\mathrm{CH}=1$ month of fattening with chestnut; $3-\mathrm{CH}=$

3 months of fattening with chestnut.

$\mathrm{a}, \mathrm{b}$ : means with different letters within row are different $(\mathrm{P}<0.05)$.

Estimated at the average live weight of $129.9 \mathrm{~kg}$. the lowest value $(\mathrm{P}<0.05)$. Also for product composition, little effect of diet was found: the only significant difference among groups was for intermuscular fat content, which was higher in 1-CH pigs, than in $0-\mathrm{CH}$ pigs $(\mathrm{P}<0.05)$. Also Coutron-Gambotti et al. (1998), in a study on the effect of substituting a concentrate diet for chestnut on Corsican pigs, found no difference in subcutaneous fat percentage whereas, in a previous work (Pugliese et al., 2007), Cinta Senese pigs pastured on chestnut forest, showed higher subcutaneous fat percentage than the control pigs reared indoor with commercial mixture that did not contain chestnut or acorn.

In Table 3 the chemical composition of the LL and PM muscles is reported. The means for the muscles are tabulated within diet because of the significant interaction between the diet and muscle effects. Overall, the 3-CH group showed the highest percentage of intramuscular fat $(\mathrm{P}<0.05)$. It is possible that chestnut led to higher adiposity during fattening because of its higher energy/protein ratio (Table 1). This effect was more significant on intramuscular fat since it is very sensitive to dietary effect (Shi-Zheng \& Su-Mei, 2009). Regarding differences between muscles, LL showed the lowest moisture percentage and the highest IMF content $(\mathrm{P}<0.05)$; this difference between muscles increased as with the length of chestnut feeding period. As reported by Cava, Estévez, Ruiz, and Morcuende (2003), there is a different trend in intramuscular fat deposition depending both on muscle fibre type and also on differences between muscles in phospholipids and fatty acid composition.

With respect to colour parameters (Table 4), the main differences were found in the LL, where the effect of chestnut supply was evident. The 1-CH and 3-CH groups showed the highest value of $\mathrm{L}^{*}, \mathrm{a}^{*}$ and $\mathrm{b}^{*}$ $(\mathrm{P}<0.05)$. These results agree with Díaz, Ros, Veiga, and Cobos (2009) who found that, muscle from pigs reared indoors and fed dried chestnut and dried sugar beet pulp, had a higher value of a* and Chroma. The effect of chestnut on colour parameters can be explained because of its tannin content. As reported by Liu et al. (2009) in a study on rabbit reared indoor, the effects of chestnut tannins on meat colour could be related to the muscle iron content. Muscle iron content increased with increasing tannin level. A study by Luciano et al. (2009) on lamb, reared in individual pens, reports that feed tannin supplementation increased $a^{*}$ and reduced $b^{*}$ values even if, as reported by Garg et al. (1992), tannins could induce a reduction of myoglobin in the muscles. The highest value of $\mathrm{L}^{*}$ showed by $1-\mathrm{CH}$ and 3-CH groups was, probably, related also to their highest value of IMF. The positive correlation between these two parameters is well known (Martin \& Fredeen, 1974).

The results on colour are instead in contrast with previous findings on pigs pastured on chestnut forest (Pugliese et al., 2007), that revealed difference for colour parameters only on subcutaneous fat, where pigs fed chestnut exhibited the lower values of $a^{*}$ and $b^{*}$ with respect to those fed commercial mixture. The comparison with this trial has to take into account the differences in rearing conditions. The animals pastured on forest had the ability to exercise and also had lower average daily gain with respect to animals fed the mixture, that may have affected the colorimetric characteristics of the meat, regardless of diet.

Table 3

Chemical composition of muscles (\% on wet weight basis).

\begin{tabular}{|c|c|c|c|c|c|c|c|}
\hline \multirow{2}{*}{$\frac{\text { Diet }}{\text { Muscle }}$} & \multicolumn{2}{|l|}{$0-\mathrm{CH}$} & \multicolumn{2}{|l|}{$1-\mathrm{CH}$} & \multicolumn{2}{|l|}{$3-\mathrm{CH}$} & \multirow[t]{2}{*}{ RSD } \\
\hline & LL & PM & LL & PM & LL & PM & \\
\hline Moisture & $72.25 b$ & $73.02 c$ & $73.27 \mathrm{c}$ & $74.60 d$ & $69.88 \mathrm{a}$ & 71.79b & 0.84 \\
\hline Ether extract & $3.34 c$ & $2.46 \mathrm{~d}$ & $4.03 \mathrm{~b}$ & $2.58 \mathrm{~d}$ & $6.10 \mathrm{a}$ & $3.41 \mathrm{c}$ & 0.82 \\
\hline Protein & 23.03 & 23.19 & 21.51 & 21.20 & 22.66 & 23.00 & 1.01 \\
\hline Ash & 1.15 & 1.28 & 1.08 & 1.21 & 1.14 & 1.28 & 0.13 \\
\hline
\end{tabular}

$0-\mathrm{CH}=$ fattening without chestnut; $1-\mathrm{CH}=1$ month of fattening with chestnut; $3-\mathrm{CH}=$ 3 months of fattening with chestnut; $\mathrm{LL}=$ Longissimus lumborum; $\mathrm{PM}=$ Psoas major. Lsmeans estimated at the average live weight of $129.9 \mathrm{~kg}$.

$\mathrm{a}, \mathrm{b}, \ldots$.. lsmeans with different letters within row are different $(\mathrm{P}<0.05)$. 
Table 4

Physical characteristics of Longissimus lumborum and of fresh and seasoned backfat.

\begin{tabular}{|c|c|c|c|c|}
\hline & \multicolumn{3}{|l|}{ Diet } & \multirow[t]{2}{*}{ RSD } \\
\hline & $0-\mathrm{CH}$ & $1-\mathrm{CH}$ & $3-\mathrm{CH}$ & \\
\hline \multicolumn{5}{|c|}{ Longissimus lumborum } \\
\hline \multicolumn{5}{|c|}{ Water holding capacity (WHC) } \\
\hline Drip loss (\%) & $2.25 b$ & $3.21 b$ & $6.64 a$ & 1.43 \\
\hline Cooking loss (\%) & $22.58 b$ & $26.37 a$ & $27.13 a$ & 3.26 \\
\hline Free water $\left(\mathrm{cm}^{2}\right)$ & 20.3 & 22.8 & 22.8 & 3.8 \\
\hline \multicolumn{5}{|l|}{ Shear force $(\mathrm{kg})$} \\
\hline On raw meat & $7.97 \mathrm{~b}$ & $8.71 \mathrm{ab}$ & $9.83 a$ & 1.66 \\
\hline On cooked meat & 13.86 & 12.76 & 12.59 & 3.03 \\
\hline \multicolumn{5}{|l|}{ Colour parameters } \\
\hline $\mathrm{L}^{*}$ & $47.02 b$ & $49.32 \mathrm{a}$ & $50.17 a$ & 2.16 \\
\hline$a^{*}$ & $10.36 b$ & $12.09 \mathrm{a}$ & $11.89 \mathrm{a}$ & 1.07 \\
\hline$b^{*}$ & $3.02 \mathrm{~b}$ & $4.39 \mathrm{a}$ & $4.56 a$ & 0.76 \\
\hline Chroma & $10.80 \mathrm{~b}$ & $12.86 a$ & $12.74 a$ & 1.14 \\
\hline Hue & $0.285 b$ & $0.350 \mathrm{a}$ & $0.366 a$ & 0.06 \\
\hline \multicolumn{5}{|l|}{ Fresh backfat } \\
\hline $\mathrm{L}^{*}$ & 80.77 & 81.39 & 80.95 & 0.81 \\
\hline$a^{*}$ & 2.45 & 2.31 & 2.50 & 0.69 \\
\hline$b^{*}$ & 2.40 & 2.75 & 2.37 & 0.80 \\
\hline Chroma & 3.46 & 3.60 & 3.46 & 0.98 \\
\hline Hue & 0.772 & 0.870 & 0.769 & 0.14 \\
\hline \multicolumn{5}{|l|}{ Seasoned backfat } \\
\hline $\mathrm{L}^{*}$ & 76.11 & 75.45 & 75.22 & 2.68 \\
\hline$a^{*}$ & 3.14 & 2.33 & 2.58 & 1.59 \\
\hline$b^{*}$ & 5.52 & 5.43 & 5.10 & 1.31 \\
\hline Chroma & 6.65 & 6.10 & 5.96 & 1.42 \\
\hline Hue & 0.915 & 0.879 & 0.975 & 0.681 \\
\hline
\end{tabular}

$0-\mathrm{CH}=$ fattening without chestnut; $1-\mathrm{CH}=1$ month of fattening with chestnut; $3-\mathrm{CH}=$ 3 months of fattening with chestnut;

Lsmeans estimated at the average live weight of $129.9 \mathrm{~kg}$.

$\mathrm{a}, \mathrm{b}$ : Ismeans with different letters within row are different $(\mathrm{P}<0.05)$.

The 3-CH group showed the highest value for shear force $(\mathrm{P}<0.05)$ of the raw meat (Table 5 ) and was significantly higher than controls but was not different from 1-CH. The 3-CH group showed the lowest water holding capacity $(\mathrm{WHC})(\mathrm{P}<0.05)$. The latter result has been confirmed by the three methods by which the WHC was determined. Regarding free water content, the differences were not significant.

Table 5

Chemical and fatty acid compositions (\% of total fatty acid) of fresh backfat.

\begin{tabular}{|c|c|c|c|c|c|c|}
\hline & \multicolumn{3}{|l|}{ Diet } & \multicolumn{2}{|c|}{ Backfat layer } & \multirow[t]{2}{*}{ RSD } \\
\hline & $0-\mathrm{CH}$ & $1-\mathrm{CH}$ & $3-\mathrm{CH}$ & Outer & Inner & \\
\hline Lipids \% & 79.06 & 79.76 & 78.32 & 77.97a & $80.11 b$ & 3.86 \\
\hline \multicolumn{7}{|l|}{ Fatty acid $\% *$} \\
\hline $\mathrm{C} 14: 0$ & 1.24 & 1.25 & 1.22 & $1.27 \mathrm{a}$ & $1.21 \mathrm{~b}$ & 0.08 \\
\hline C16:0 & $24.13 a$ & $23.47 b$ & $23.11 b$ & 22.96a & $24.19 b$ & 0.80 \\
\hline C16:1 & $1.94 a$ & $1.97 \mathrm{a}$ & $1.83 \mathrm{~b}$ & $2.05 a$ & $1.78 \mathrm{~b}$ & 0.16 \\
\hline C18:0 & $13.01 \mathrm{a}$ & $12.59 b$ & $12.38 b$ & $11.46 a$ & $13.86 b$ & 0.78 \\
\hline C18:1 & $46.68 \mathrm{a}$ & 46.84ab & $47.35 b$ & 47.89a & $46.03 b$ & 0.97 \\
\hline C18:2 & $10.11 \mathrm{a}$ & $10.75 b$ & $10.82 \mathrm{~b}$ & 11.10a & $10.02 b$ & 0.90 \\
\hline C18:3 & $0.44 a$ & $0.55 b$ & $0.67 c$ & $0.58 \mathrm{a}$ & $0.53 b$ & 0.07 \\
\hline C20:1 & $1.07 a$ & 1.10ab & $1.16 \mathrm{~b}$ & $1.15 \mathrm{a}$ & $1.07 \mathrm{~b}$ & 0.14 \\
\hline C20:2 & $0.51 \mathrm{a}$ & $0.55 b$ & $0.55 b$ & $0.60 \mathrm{a}$ & $0.48 b$ & 0.06 \\
\hline SFA & $38.88 \mathrm{a}$ & $37.82 b$ & $37.16 b$ & $36.16 a$ & $39.74 b$ & 1.37 \\
\hline MUFA & $49.94 a$ & 50.17ab & $50.59 \mathrm{~b}$ & 51.38a & $49.09 b$ & 1.02 \\
\hline PUFA-n - 3 & $0.44 a$ & $0.55 b$ & $0.67 c$ & $0.59 a$ & $0.53 b$ & 0.07 \\
\hline PUFA-n -6 & $10.72 \mathrm{a}$ & $11.44 b$ & $11.56 \mathrm{~b}$ & 11.86a & $10.62 b$ & 0.97 \\
\hline PUFA & $11.17 \mathrm{a}$ & $12.00 \mathrm{~b}$ & $12.24 \mathrm{~b}$ & $12.44 a$ & $11.16 \mathrm{~b}$ & 1.03 \\
\hline
\end{tabular}

$0-\mathrm{CH}=$ fattening without chestnut; $1-\mathrm{CH}=1$ month of fattening with chestnut; $3-\mathrm{CH}=$ 3 months of fattening with chestnut.

$\mathrm{a}, \mathrm{b}, \ldots$. lsmeans with different letters, within criterion and within row, are different $(\mathrm{P}<0.05)$.

Lsmeans estimated at the average live weight of $129.9 \mathrm{~kg}$, other fatty acids detected and considered in the composite fractions: C12:0, C15:0,C17:0, C17:1, C20:0, C20:4, and C20:3.
These are surprising results and difficult to interpret. It is probable that the higher fat content in LL muscle, especially in 3-CH group, contributes to the highest cooking losses because, as reported by Lawrie (1998), some of juice on cooking can represent non-aqueous fluid, since the high temperatures can melt fat and tend to destroy the structures retaining it.

The low WHC showed by 1 and 3-CH groups, may suggest a direct effect of chestnut on the ability of the muscle to retain water resulting in possible negative effects on the technological properties of the meat and, in particular, on the technological yields. However, this result has not been confirmed by other similar studies.

Concerning the fatty acid composition of the fresh fat (Table 5), the animals fed chestnut during the whole fattening period showed the highest level of MUFA, PUFA $n-3$ and PUFA $n-6(P<0.05)$. These results reflect the fatty acid composition of chestnut which has more MUFA and PUFA contents with respect to mixture (Table 1). So, considering the daily feed intake of dry matter of $2.7 \mathrm{~kg}$ for all animals, it is possible to calculate the feed intake of MUFA, PUFA $\mathrm{n}-3$ and PUFA $\mathrm{n}-6$ that was $24.57,4.32$, and $24.84 \mathrm{~g} /$ day respectively for animal $1-\mathrm{CH}$ and 3-CH groups, and 8.1, 1.89, and $19.44 \mathrm{~g}$ /day respectively for 0 - $\mathrm{CH}$ group. This average daily intake led to a deposition of fatty acid, especially for PUFA $n-3$ and $n-6$, increasing in quantity, according with the length of the period of chestnut fattening. In fact, 1- $\mathrm{CH}$ group was placed, as concerns the absolute value, in an intermediate position for all unsaturated fatty acids detected but it was not significantly different from 3-CH group. Coutron-Gambotti et al. (1998) with Corsican pigs, found the highest percentage of PUFA in the adipose tissue of animals fed chestnut while no diet effect was found on MUFA content.

Table 5 reports the effect of backfat layer on fatty acid composition. The inner layer was richer in SFA and poorer in MUFA and PUFA $(\mathrm{P}<0.05)$ than the outer one, in general agreement with the results obtained by other authors (Girard, Bout, \& Salort, 1988; Rossi \& Corino, 2002; Zappa et al., 1992). The reason of the variation in the unsaturation level seems to be linked to the cellularity of adipose tissue and in particular to the highest diameter of adipocytes of inner layer (Geri, Zappa, \& Franci, 1986). In fact, the degree of unsaturation varies inversely with the diameter of adipocytes (Wood, 1973). Moreover, it is probable that the inner layer of subcutaneous adipose tissue exhibits larger de novo lipogenesis, consequently, the polyunsaturated fatty acids of feed origin (particularly C18:2) are diluted with more endogenous fatty acids than in the outer layer, as reported by Monziols, Bonneau, Davenel, and Kouba (2007) who also found the same results of ours on the two layers of the subcutaneous fat taken from loin.

In Table 6, the fatty acid composition of seasoned fat is reported. The 3-CH group showed the highest value of MUFA and PUFA $(\mathrm{P}<0.05)$ while $1-\mathrm{CH}$ group, contrary to what related for fresh fat, was not different from 0 - $\mathrm{CH}$ group. In order to achieve a significant characterization of seasoned products, these results have to be considered in the planning of administration of chestnut or, in case of pasture in the forest, in the length of grazing time. This is important in particular for the enhancement of oleic acid which is highly related to a wide number of sensory traits. In fact, large correlations appeared between oleic acid and the brightness, oiliness, juiciness, sweetness, fat hardness and cured aroma, as found on Iberian dry-cured ham by Carrapiso, Bonilla, and Garcìa (2003). Cava, Ruiz, Ventanas, and Antequera (1999b), studying the effects of the feeding system on the fatty acid composition of seasoned products, reported high concentrations of oleic acid in Iberian ham, promoted by acorn pasturing that, together with the typical marbling of the meat, is considered essential for appropriate ripening and flavour development of dry-cured products. Nevertheless, it has to be stressed that the level of oleic acid percentage in adipose tissue of pigs fed chestnut is, generally, lower than those found in pigs fed acorn (Pugliese, Sirtori, Ruiz, et al., 2009). Moreover, chestnut, because of its fatty acid composition, also enhances the level of PUFA, as shown in Table 6, with a reasonable risk of worsening technological traits. The 
Table 6

Chemical and fatty acid compositions (\% of total fatty acid) of seasoned backfat.

\begin{tabular}{|c|c|c|c|c|c|c|}
\hline & \multicolumn{3}{|l|}{ Diet } & \multicolumn{2}{|c|}{ Backfat layer } & \multirow[t]{2}{*}{ RSD } \\
\hline & $0-\mathrm{CH}$ & $1-\mathrm{CH}$ & $3-\mathrm{CH}$ & Outer & Inner & \\
\hline Lipids \% & $68.63 a$ & $72.25 b$ & $74.37 b$ & $73.72 a$ & $69.79 b$ & 3.82 \\
\hline \multicolumn{7}{|l|}{ Fatty acid \%* } \\
\hline C14:0 & $1.45 a$ & $1.43 a$ & $1.38 \mathrm{~b}$ & $1.46 a$ & $1.37 \mathrm{~b}$ & 0.09 \\
\hline C16:0 & $25.84 a$ & $25.75 a$ & $25.05 b$ & $24.68 \mathrm{a}$ & $26.41 b$ & 0.74 \\
\hline C16:1 & $1.92 \mathrm{a}$ & $1.92 \mathrm{a}$ & $1.78 b$ & $2.07 a$ & $1.68 b$ & 0.18 \\
\hline C18:0 & $14.16 \mathrm{a}$ & $13.58 \mathrm{a}$ & $13.21 \mathrm{~b}$ & $12.24 a$ & $15.06 \mathrm{~b}$ & 0.90 \\
\hline C18:1 & $46.82 a$ & 47.35ab & $47.82 \mathrm{~b}$ & $48.37 \mathrm{a}$ & $46.29 b$ & 1.00 \\
\hline $\mathrm{C} 18: 2$ & $7.63 a$ & $7.97 a$ & $8.43 b$ & $8.86 a$ & $7.15 b$ & 0.77 \\
\hline C18:3 & $0.26 a$ & $0.26 a$ & $0.42 \mathrm{~b}$ & $0.38 a$ & $0.24 \mathrm{~b}$ & 0.09 \\
\hline $\mathrm{C} 20: 1$ & 1.00 & 0.93 & 0.99 & $0.99 a$ & $0.96 \mathrm{~b}$ & 0.15 \\
\hline $\mathrm{C} 20: 2$ & $0.28 \mathrm{ab}$ & $0.24 a$ & $0.32 \mathrm{~b}$ & $0.34 a$ & $0.22 \mathrm{~b}$ & 0.09 \\
\hline SFA & $41.88 \mathrm{a}$ & $41.15 a$ & $40.05 b$ & $38.80 a$ & $43.26 b$ & 1.48 \\
\hline MUFA & $49.91 a$ & $50.36 \mathrm{ab}$ & $50.75 b$ & $51.58 \mathrm{a}$ & $49.10 \mathrm{~b}$ & 1.05 \\
\hline PUFA $-n-3$ & $0.26 a$ & $0.26 a$ & $0.42 \mathrm{~b}$ & $9.23 a$ & $7.38 \mathrm{~b}$ & 0.09 \\
\hline PUFA $-n-6$ & $7.92 \mathrm{a}$ & $8.22 \mathrm{a}$ & $8.77 b$ & $0.38 \mathrm{a}$ & $0.24 b$ & 0.81 \\
\hline PUFA & $8.19 a$ & $8.48 a$ & $9.19 \mathrm{~b}$ & $9.61 \mathrm{a}$ & $7.63 b$ & 0.88 \\
\hline MDA (mg/kg) & 3.70ab & $3.89 a$ & $3.23 b$ & & & 1.02 \\
\hline
\end{tabular}

$0-\mathrm{CH}=$ fattening without chestnut; $1-\mathrm{CH}=1$ month of fattening with chestnut; $3-\mathrm{CH}=$ 3 months of fattening with chestnut.

$\mathrm{a}, \mathrm{b}, \ldots$. lsmeans with different letters, within criterion and within row, are different $(\mathrm{P}<0.05)$.

* Lsmeans estimated at the average live weight of $129.9 \mathrm{~kg}$, other fatty acids detected and considered in the composite fractions: C12:0, C15:0,C17:0, C17:1, C20:0, C20:4, and c20:3.

latter, however, seems to be averted, as the data on MDA content demonstrated. In fact, 3-CH group showed a MDA level similar to those found in $0-\mathrm{CH}$ group. This result could be linked to a higher level of natural antioxidant, such tocopherol, contained in chestnut, even if it shows a high level of $\gamma$-tocopherol than $\alpha$-tocopherol (Pugliese, Sirtori, D'Adorante, et al., 2009). The former seems to have a lower antioxidant activity, as reported by Amaral, Rui Alves, Seabra, and Oliveira (2005), but other findings on this topic (Daza, Rey, Ruiz, \& Lopez-Bote, 2005; Pugliese, Sirtori, D'Adorante, et al., 2009) demonstrate that also $\gamma$-tocopherol can act against oxidation reactions.

In Table 7, the fatty acid composition according to seasoning time is reported. The MUFA percentage remained constant during the time of seasoning while PUFA $n-3$ and PUFA $n-6$ decreased significantly according to time of maturing of the product. These results are in contrast with Coutron-Gambotti and Gandemer (1999) who found a decrease in PUFA content only in free fatty acids but not in total lipid in the adipose tissue. These authors reported that the decrease of the polyunsaturated content of free fatty acids, was due to their higher susceptibility to oxidation reactions than saturated and monounsaturated fatty acids. This could be the reason for the decrease of PUFA content also in our trial. Moreover, our results confirm those reported by several authors (Moltiva, Toldrá, Aristoy, \& Flores, 1993; Martín, Córdoba, Ventanas, \& Antequera, 1999) on the period of seasoning during which the main change in fatty acid composition occurred. According to data shown in Table 7, it seems that the most significant decrease in PUFA content happens within the first 30 days of seasoning, even if the reduction of PUFA level is significant over the entire seasoning period. The relationship between decreasing of PUFA level and the oxidation reactions is demonstrated also by the level of MDA content that significantly increased according to seasoning time.

In Table 8, the linear regression coefficients of the trend of fatty acid percentage, for each experimental group, are reported. It is evident that the trend during seasoning of the main fatty acids, was the same in the three groups. However, differences among diet groups in the extent of change during the process were recorded, in particular for the PUFA $\mathrm{n}-3$ content, where the $3-\mathrm{CH}$ groups showed the more pronounced decrease over time. In spite of this, the 3-CH group showed the highest value of PUFA $n-3$ at the end of the process, as shown in Table 7.
Table 7

Chemical and fatty acid composition (\% of total fatty acids) of backfat according to seasoning times.

\begin{tabular}{llllll}
\hline & \multicolumn{2}{l}{ Seasoning time $(\mathrm{d})$} & & RSD \\
\cline { 2 - 4 } & 0 & 30 & 60 & 90 & \\
\hline Lipids \% & $79.53 \mathrm{a}$ & $71.26 \mathrm{~b}$ & $66.95 \mathrm{c}$ & $71.38 \mathrm{~b}$ & 5.08 \\
Fatty acid \%* & & & & & \\
C14:0 & $1.25 \mathrm{a}$ & $1.41 \mathrm{~b}$ & $1.28 \mathrm{a}$ & $1.41 \mathrm{~b}$ & 0.12 \\
C16:0 & $23.65 \mathrm{a}$ & $24.91 \mathrm{~b}$ & $24.88 \mathrm{~b}$ & $25.52 \mathrm{c}$ & 0.81 \\
C16:1 & $1.94 \mathrm{a}$ & $1.92 \mathrm{a}$ & $1.22 \mathrm{~b}$ & $1.89 \mathrm{a}$ & 0.21 \\
C18:0 & $12.65 \mathrm{a}$ & $12.94 \mathrm{a}$ & $13.42 \mathrm{~b}$ & $13.69 \mathrm{~b}$ & 0.91 \\
C18:1 & $47.01 \mathrm{a}$ & $47.51 \mathrm{~b}$ & $47.33 \mathrm{ab}$ & $47.31 \mathrm{ab}$ & 1.12 \\
C18:2 & $10.49 \mathrm{a}$ & $9.04 \mathrm{~b}$ & $8.55 \mathrm{c}$ & $8.05 \mathrm{~d}$ & 0.96 \\
C18:3 & $0.56 \mathrm{a}$ & $0.44 \mathrm{~b}$ & $0.33 \mathrm{c}$ & $0.32 \mathrm{c}$ & 0.11 \\
C20:1 & $1.11 \mathrm{a}$ & $0.95 \mathrm{~b}$ & $0.95 \mathrm{~b}$ & $0.98 \mathrm{~b}$ & 0.17 \\
C20:2 & $0.54 \mathrm{a}$ & $0.40 \mathrm{~b}$ & $0.42 \mathrm{~b}$ & $0.30 \mathrm{c}$ & 0.09 \\
SFA & $38.01 \mathrm{a}$ & $39.63 \mathrm{~b}$ & $40.23 \mathrm{c}$ & $41.03 \mathrm{~d}$ & 1.53 \\
MUFA & 50.30 & 50.49 & 50.68 & 50.33 & 1.19 \\
PUFA $-\mathrm{n}-3$ & $0.56 \mathrm{a}$ & $0.44 \mathrm{~b}$ & $0.34 \mathrm{c}$ & $0.32 \mathrm{c}$ & 0.11 \\
PUFA $-\mathrm{n}-6$ & $11.17 \mathrm{a}$ & $9.49 \mathrm{~b}$ & $9.05 \mathrm{c}$ & $8.36 \mathrm{~d}$ & 1.01 \\
PUFA & $11.73 \mathrm{a}$ & $9.92 \mathrm{~b}$ & $9.39 \mathrm{c}$ & $8.68 \mathrm{~d}$ & 1.09 \\
MDA (mg/kg) & & $2.78 \mathrm{a}$ & $3.01 \mathrm{ab}$ & $3.56 \mathrm{~b}$ & 1.02 \\
\hline
\end{tabular}

$\mathrm{a}, \mathrm{b}, \ldots$..: lsmeans with different letters within row, are different $(\mathrm{P}<0.05)$.

* Lsmeans estimated at the average live weight of $129.9 \mathrm{~kg}$, other fatty acids detected and considered in the composite fractions: C12:0, C15:0,C17:0, C17:1, C20:0, C20:4, and C20:3.

\section{Conclusion}

Substituting concentrate for chestnut significantly affects meat and fat quality. Chestnut seems to worsen physical characteristics of the lean (lower WHC and higher shear force) in spite of the higher intramuscular fat that it brings. Moreover chestnut supply led to a greater unsaturation level of adipose tissue especially with respect to PUFA $n-3$ and $n-6$. This latter result could be positively considered from the dietetic point of view with some negative consequences from technological aspects. However, the low level of MDA shown by pigs fed chestnuts seems to prevent the risk of a high oxidation of lipids.

\section{Acknowledgements}

We would like to thank "Cassa di Risparmio di Firenze" for providing the financial support for SAS licence and the managerial and technical staff of the Ufficio Territoriale per la Biodiversità di Siena. This study was supported by grant of PRIN-MIUR prot. 2005077118_001.

\section{Table 8}

Linear regression coefficients of the evolution of chemical and fatty acid compositions of backfat along the seasoning time.

\begin{tabular}{lcccl}
\hline & \multicolumn{2}{l}{ Diet } & \multicolumn{2}{l}{$\begin{array}{l}\text { Differences among diets } \\
\mathrm{P}<0.05\end{array}$} \\
\cline { 2 - 4 } & $0-\mathrm{CH}$ & $1-\mathrm{CH}$ & $3-\mathrm{CH}$ & \\
\hline Lipids \% & $\mathbf{- 0 . 1 3}$ & $-\mathbf{0 . 0 9}$ & $-\mathbf{0 . 0 7}$ & $*$ \\
Fatty acid \%* & & & & \\
C16:0 & $\mathbf{0 . 0 1 6}$ & $\mathbf{0 . 0 2 0}$ & $\mathbf{0 . 0 2 0}$ & \\
C18:0 & $\mathbf{0 . 0 1 3}$ & $\mathbf{0 . 0 1 2}$ & $\mathbf{0 . 0 1 1}$ & \\
C18:1 & 0.0014 & 0.0013 & 0.0045 & \\
C18:2 & $-\mathbf{0 . 0 2 7}$ & $-\mathbf{0 . 0 2 6}$ & $-\mathbf{0 . 0 2 5}$ & \\
C18:3 & $-\mathbf{0 . 0 0 2}$ & $-\mathbf{0 . 0 0 3}$ & $-\mathbf{0 . 0 0 3}$ & $*$ \\
SFA & $\mathbf{0 . 0 3 0}$ & $\mathbf{0 . 0 3 3}$ & $\mathbf{0 . 0 3 3}$ & \\
MUFA & 0.0010 & -0.0005 & 0.0023 & \\
PUFA $-\mathrm{n}-3$ & $-\mathbf{0 . 0 0 1 9}$ & $-\mathbf{0 . 0 0 2 8}$ & $-\mathbf{0 . 0 0 3 5}$ & $*$ \\
PUFA $-\mathrm{n}-6$ & $\mathbf{- 0 . 0 2 9}$ & $-\mathbf{0 . 0 3 0}$ & $\mathbf{- 0 . 0 2 9}$ & \\
PUFA & $-\mathbf{0 . 0 3 1}$ & $-\mathbf{0 . 0 3 3}$ & $-\mathbf{0 . 0 3 3}$ & \\
MDA (mg/kg of fat) & $\mathbf{0 . 5 7}$ & $\mathbf{0 . 3 4}$ & 0.25 & \\
\hline
\end{tabular}

$0-\mathrm{CH}=$ fattening without chestnut; $1-\mathrm{CH}=1$ month of fattening with chestnut; $3-\mathrm{CH}=$ 3 months of fattening with chestnut.

The significant regression coefficients are in bold $(\mathrm{P}<0.05)$. 


\section{References}

Amaral, J. S., Rui Alves, M., Seabra, R. M., \& Oliveira, B. P. P. (2005). Vitamin E composition of walnuts (Juglans regia L.): a 3-year comparative study of different cultivars. Journal of Agriculture and Food Chemistry, 53, 5467-5472.

Andrés, A. I., Cava, R., Mayoral, A. I., Tejeda, J. F., Morcuende, D., \& Ruiz, J. (2001). Oxidative stability and fatty acid composition of pig muscles as affected by rearing system, crossbreeding and metabolic type of muscle fibre. Meat Science, 59, 39-47.

AOAC (1990). (15th ed.). Official methods of analysis of the association of official analytical chemist, No. 960.39, Washington: Association of the Office of Analytical Chemists.

Boccard, R., Buchter, L., Casteels, E., Cosentino, E., Dransfield, E., Hood, D. E., et al (1981). Procedures for measuring meat quality characteristics in beef production experiments report of a working group in the commission of the European Communities (CEC) beef production research programme. Livestock Production Science, 385-397.

Campodoni, G. Acciaioli, A., \& Bozzi, R. (2010). Model of sustainable management of pig farming on pastures in Tuscany. Proceedings of the 6th International Symposium on the Mediterranean Pig, October 14th-16th, Cordoba, Andalusia, Spain.

Carrapiso, A. I., Bonilla, F., \& Garcìa, C. (2003). Effect of crossbreeding and rearing system on sensory characteristics of Iberian ham. Meat Science, 65, 623-629.

Cava, R., Estévez, M., Ruiz, J., \& Morcuende, D. (2003). Physicochemical characteristics of three muscles from free-range reared Iberian pigs slaughtered at $90 \mathrm{~kg}$ live weight. Meat Science, 63, 533-541.

Cava, R., Ruiz, J., Ventanas, J., \& Antequera, T. (1999a). Oxidative and lipolytic changes during ripening of Iberian hams as affected by feeding regime: extensive feeding and $\alpha$-tocopheryl acetate supplementation. Meat Science, 52, 165-172.

Cava, R., Ruiz, J., Ventanas, J., \& Antequera, T. (1999b). Effect of $\alpha$-tocopheryl acetate supplementation and the extensive feeding of pigs on the volatile aldehydes during the maturation of Iberian ham. Food Science and Technology International, 5, 235-241.

Cava, R., Ventanas, J., Tejeda, J. F., Ruiz, J., \& Antequera, T. (2000). Effect of free-range rearing and $\alpha$-tocopherol and copper supplementation on fatty acid profiles and susceptibility to lipid oxidation of fresh meat from Iberian pigs. Food Chemistry, $68,51-59$.

Coutron-Gambotti, C., \& Gandemer, G. (1999). Lipolysis and oxidation in subcutaneous adipose tissue during dry-cured ham processing. Food Chemistry, 64, 95-101.

Coutron-Gambotti, C., Gandemer, G., \& Casabianca, F. (1998). Effects of substituting a concentrated diet for chestnuts on the lipid traits of muscle and adipose tissues in Corsican and Corsican $\times$ Large White pigs reared in sylvo-pastoral system in Corsica. Meat Science, 50, 163-174.

Daza, A., Rey, A. I., Ruiz, J., \& Lopez-Bote, C. J. (2005). Effects of feeding in free-range conditions or in confinement with different dietary MUFA/PUFA ratios and $\alpha$-tocopheryl acetate, on antioxidant accumulation and oxidative stability in Iberian pigs. Meat Science, 69, 151-163.

Diaz, I., Garcia Regueiro, J. A., Casillas, M., \& De Pedro, E. (1996). Triglyceride composition of fresh ham fat from Iberian pigs produced with different systems of anima nutrition. Food Chemistry, 55, 383-387.

Díaz, O., Ros, C., Veiga, A., \& Cobos, Á. (2009). Including chestnuts and sugar beet pulp in diets for pigs: the effects on the quality of pork meat and the sensory properties of dry-cured sausage (chorizo gallego). Journal of Muscle Foods, 20, 449-464.

Folch, J., Lees, M., \& Stanley, G. H. S. (1957). A simple method for the isolation and purification of total lipids from animal tissues. Journal of Biological Chemistry, 226, 497-509.

Franci, O., \& Pugliese, C. (2007). Italian autochthonous pigs: progress report and research perspectives. Italian Journal of Animal Science, 6(Suppl. 1), 663-671.

Garg, S. K., Makkar, H. P. S., Nagal, K. B., Sharma, S. K., Wadhwa, D. R., \& Singh, B. (1992). Oak (Quercus incana) leaf poisoning in cattle. Veterinary and Human Toxicology, 34, 161-164.

Geri, G., Zappa, A., \& Franci, O. (1986). Influenza dello sviluppo corporeo e della localizzazione sulla cellularità del tessuto adiposo nei suini. Zootecnica e Nutrizione Animale, 12, 9-24.

Girard, J. P., Bout, J., \& Salort, D. (1988). Lipides et qualités du tissu adipeux, facteurs de variation. Journéss de la Recherche Porcine en France, 20, 255-278.
Grau, R., \& Hamm, R. (1952). Eine einfache methode zur bestimmung der wasserbinding im fleich. Fleischwirtschaft, 4, 295-297.

Lawrie, R. A. (1998). In R. A. Lawrie (Ed.), Lawrie's meat science. : Woodhead Publishing Limited.

Liu, H. W., Gai, F., Gasco, L., Brugiapaglia, A., Lussiana, C., Guo, K. J., et al. (2009). Effects of chestnut tannins on carcass characteristics, meat quality, lipid oxidation and fatty acid composition of rabbits. Meat Science, 83, 678-683.

Lopez-Bote, C. J., Toldrà, F. Daza, A, Ferrer, J. M., Menoyo, D., Siliò, L., et al. (2008). Effect of exercise on skeletal muscle proteolytic enzyme activity and meat quality characteristics in Iberian pigs. Meat Science, 79, 71-76.

Luciano, G., Monahan, F. J., Vasta, V., Biondi, L., Lanza, M., \& Priolo, A. (2009). Dietary tannins improve lamb meat colour stability. Meat Science, 81, 120-125.

Martín, L., Córdoba, J. J., Ventanas, J., \& Antequera, T. (1999). Changes in intramuscular lipids during ripening of Iberian dry-cured ham. Meat Science, 51, 129-134.

Martin, A. H., \& Fredeen, H. T. (1974). Pork quality in relation to carcass fatness and muscling. Canadian Journal of Animal Science, 54, 137-143.

Moltiva, M. J., Toldrá, F., Aristoy, M. C., \& Flores, J. (1993). Subcutaneous adipose tissue lipolysis in the processing of dry-cured ham. Journal of Food Biochemistry, 16, 323-327.

Monziols, M., Bonneau, M., Davenel, A., \& Kouba, M. (2007). Comparison of the lipid content and fatty acid composition of intermuscular and subcutaneous adipose tissue in pig carcasses. Meat Science, 76, 54-60.

Pérez-Palacios, T., Antequera, T., Durán, M. L., Caro, A., Rodríguez, P. G., \& Ruiz, J. (2010). MRI-based analysis, lipid composition and sensory traits for studying Iberian dry-cured hams from pigs fed with different diets. Food Research International, 43, 248-254.

Pikul, J., Leszczynski, D. E., \& Kummerow, F. A. (1983). Elimination of sample autoxidation by butylated hydroxytoluene additions before thiobarbituric acid assay for malonaldehyde in fat from chicken meat. Journal of Agriculture and Food Chemistry, 31, 1338-1342.

Pugliese, C., Bozzi, R., Campodoni, G., Acciaioli, A., Franci, O., \& Gandini, G. (2005). Performance of Cinta Senese pigs reared outdoors and indoors. 1 Meat and subcutaneous fat characteristics. Meat Science, 69, 459-464.

Pugliese, C., Calagna, G., Chiofalo, V., Moretti, V. M., Margiotta, S., Franci, O., et al. (2004). Comparison of the performances of Nero Siciliano pigs reared indoors and outdoors. 2. Joints composition, meat and fat traits. Meat Science, 68, 523-528.

Pugliese, C. Pianaccioli, L, Sirtori, F., Acciaioli, A \& Eranci, O. (2007). Effect of pasture on chestnut wood on fat and meat quality of Cinta Senese. Option Méditerranéennes, 76, 263-267 110

Pugliese, C., Sirtori, F., D'Adorante, S., Parenti, S., Rey, A., Lopez-Bote, C. J., et al. (2009). Effect of pasture on oak and chestnut plantation on chemical and sensorial traits of cured lard of Cinta Senese pigs. Italian Journal of Animal Science, 8, 131-142.

Pugliese, C., Sirtori, F., Ruiz, J. S., Martin, D., Parenti, S., \& Franci, O. (2009). Effect of pasture on chestnut or acorn on fatty acid composition and aromatic profile of fat of Cinta Senese dry-cured ham. Grasas y Aceites, 60, 271-276.

Rossi, R., \& Corino, C. (2002). Influence of long-term nutrition with different dietary fats on fatty acid composition of heavy pigs backfat. Italian Journal of Animal Science, 1, 7-16.

SAS (2003). SAS/STAT software, release 9.1. Cary, NC: SAS Institute Inc.

Shi-Zheng, G., \& Su-Mei, Z. (2009). Physiology, affecting factors and strategies for control of pig meat intramuscular fat. Recent Patents on Food, Nutrition E' Agriculture, $1,59-74$.

Wood, J. D. (1973). The fatty acid composition of backfat from Pietrain and Large White pigs. Animal Production, 17, 281-285.

Zappa, A., Franci, O., Poli, B. M., Campodoni, G., Geri, G., \& Bittante, G. (1992). Incrocio di scrofe Large White con verri Landrace belga, Duroc e Spotted Poland: effetto sulle caratteristiche isto-chimiche del tessuto adiposo. Zootecnica e Nutrizione Animale, $18,147-156$

Zumbo, A., Lo Presti, V., Di Rosa, A. R., Pruiti, V., Di Marco, V., \& Piccolo, D. (2007). Fatty acid profile of intramuscular fat of "Nero Siciliano" fattening pigs fed with different diets. Proceedings of the 6th International Symposium on the Mediterranean Pig, Messina - Capo d'Orlando, Italy, October 11-13 (pp. 224-227). 